\title{
President Lincoln's Meetings with African Americans
}

\author{
MICHAEL BURLINGAME
}

Lincoln not only greeted African American callers at White House receptions cordially and respectfully, as described in the previous issue of this journal, but he also showed no aversion to receiving individual black callers and listening attentively to their requests, opinions, and appeals.

Before the Civil War, presidents had invited blacks to call at the White House on only two known occasions. The first occurred when James Madison met with Paul Cuffe, a wealthy black merchant and shipbuilder in 1812. The second occurred 30 years later, when John Tyler invited Bishop Daniel Payne of the African Methodist Episcopal Church to preach a funeral sermon for the president's body servant. ${ }^{1}$

If Bishop Payne was the second known black man to be hosted at the White House, on April 14, 1862, he became the first such caller during Lincoln's administration. Two days earlier, Congress had passed a bill, then awaiting his signature, abolishing slavery in the District of Columbia. Lincoln, who had been conversing with Illinois Congressman Elihu Washburne when the bishop sent in his card, met Payne at the office door, shook his hand, and led him to a seat by the fireplace, near the congressman. They were soon joined by Carl Schurz, recently returned from Madrid, where he had been serving as America's minister to the Spanish court.

The bishop recalled that after a few pleasantries, he said to Lincoln, "I am here to learn whether or not you intend to sign the bill of emancipation."

The president replied, "There was a company of gentlemen here to-day requesting me by no means to sign it."

1. Part I of this article appeared in the Summer 2020 issue. / Sheldon H. Harris, Paul Cuffe: Black America and the African Return (New York: Simon and Schuster, 1971), 57-60; Daniel Alexander Payne, Recollections of Seventy Years (Nashville, Tennessee: Publishing House of the A.M.E. Sunday School Union, 1888), 148. 
Schurz interjected, "But, Mr. President, there will be a committee to beg that you fail not to sign it; for all Europe is looking to see that you fail not."

The bishop continued, "Mr. President, you will remember that on the eve of your departure from Springfield, you begged the citizens of the republic to pray for you."

"Yes."

"From that moment we, the colored citizens of the republic, have been praying: 'O Lord just as thou didst cause the throne of David to wax stronger and stronger, while that of Saul should wax weaker and weaker, so we beseech thee cause the power at Washington to grow stronger and stronger, while that at Richmond shall grow weaker and weaker."'

Lincoln's response was evasive. "Well, I must believe that God has led me thus far, for I am conscious that I never would have accomplished what has been done if he had not been with me to counsel and to shield."

Frustrated by the president's failure to answer his question directly, Payne decided that since he had been in the White House for about 45 minutes that it was time to withdraw. So he presented his host a copy of the A. M. E. Church's monthly magazine and a recent issue of its weekly newspaper, The Christian Recorder, to give the president some idea of what the church was "doing to improve the character and condition of our people in the republic," and departed. In his memoirs, the bishop wrote that there "was nothing stiff or formal in the air and manner of His Excellency-nothing egotistic." The president "received and conversed with me as though I had been one of his intimate acquaintances or one of his friendly neighbors. I left him with a profound sense of his real greatness and of his fitness to rule a nation composed of almost all the races on the face of the globe." ${ }^{2}$

An account of this interview appeared in The Christian Recorder: "Bishop Payne had quite a long and profitable interview with President Lincoln." The bishop assured his host that he was in "the prayers of the colored people." The president in turn assured Bishop Payne "of his reliance on Divine Providence-expressing a hearty wish for the welfare of the colored race."

The following day (April 15), Lincoln met with an eminent black abolitionist, Alexander Crummell, an Episcopal priest visiting from his home in Liberia, whose government he was representing as a

2. Payne, Recollections, $146-148$.

3. Washington correspondence by "Sacer," n.d., Christian Recorder (Philadelphia), 26 April 1862. 
"commissioner of emigration." Accompanying him was another Liberian commissioner, John D. Johnson, a Monrovia merchant and former barber/saloonkeeper in Brooklyn. ${ }^{4}$ Both were lobbying the president, who had just been authorized by Congress to spend $\$ 100,000$ on efforts to colonize Washington's blacks, including those who were being emancipated. The only press account of that conversation erroneously stated that the visitors "urged the compulsory transportation of freed slaves to Liberia." When Crummell and Johnson asked Lincoln to correct that mistake, he wrote them stating "that neither you nor any one else have ever advocated in my presence the compulsory transportation of freed slaves to Liberia, or elsewhere."

Crummell and Johnson probably asserted "the claims which the government and people of Liberia have upon the sympathy of the civilized world" and provided Lincoln with "the necessary information preparatory to a formal recognition of the Liberian republic." In all likelihood, the commissioners conveyed the desire of the Liberian government "to make arrangements for the comfortable settlement in Liberia of such of the free blacks" of the U.S. "as choose to emigrate thither." Further, they may well have explained that the Liberian government "offers to all men who choose to immigrate to that country a free passage for themselves and families, six months support and medical attendance free after arrival in the country, and sufficient farmlands-say one hundred acres to each family; and the migrants are not bound to remain in the country unless they are pleased with it."

Six months later, the president met with another African American clergyman promoting emigration to Liberia, the Rev. Mr. Chauncey Leonard of Washington, "a light mulatto, of good address and abilities," who was accompanied by Thomas S. Malcom, a representative of the Pennsylvania Colonization Society. ${ }^{7}$ On January 30, 1863, those two men revisited the White House, where Lincoln agreed to

4. Sarah J. Hale, ed., Liberia; or, Mr. Peyton's Experiments (New York: Harper \& Brothers, 1853), 272; New York Evening Post, 1 April 1862.

5. Lincoln to Crummell and Johnson, Washington, 5 May 1862, in the Boston Herald, [ca. 11 May 1862], photocopy in Phillip W. Magness, "Lincoln and Colonization," https: / /www.essentialcivilwarcurriculum.com/lincoln-and-colonization.html.

6 . These were, according to Johnson, his instructions from the Liberian government. New York Evening Post, 1 April 1862.

7. Philadelphia Evening Telegraph, 20 October 1866; Phillip Magness and Sebastian Page, Colonization After Emancipation: Lincoln and the Movement for Black Resettlement (Columbia: University of Missouri Press, 2011), 27. 
fund the minister's trip to investigate conditions in Liberia. ${ }^{8} \mathrm{~A}$ few days thereafter, Leonard sailed for Monrovia "as a pioneer of about fifty Baptists, who are to follow on the 1st of May with two or three preachers." ${ }^{\prime 9}$ Years later, he said that Lincoln commissioned him to inspect "the acclimating houses" in Liberia ("acclimating fever" was highly lethal) and "obtain a percentage of the sickness and death of the colored colonists who had emigrated from the United States." The president was reluctant to urge resettlement in that country, especially after Leonard submitted a report that "was not favorable to sending the colored people in a mass to Africa, mostly on account of the inconveniences while acclimating and lack of provisions." ${ }^{10}$ Early in 1864, Leonard became sick and returned to the U.S., where Lincoln appointed him chaplain at the L'Ouverture Hospital for Freedmen in Alexandria, Virginia. He was only one of the handful of blacks appointed as chaplains. ${ }^{11}$

Leonard's reminiscences about his fact-finding mission may not be entirely reliable. In 1866, he was arrested for defrauding a Philadelphian of $\$ 200$, and six years later, a Baptist newspaper in that city described him as "an utterly vile reprobate" who "at different times collected money for various objects." Police court records in Washington indicated that Leonard "has been repeatedly before the court for indecent exposure and kindred infamous offenses, and has been found guilty and sentenced to the workhouse. He has been a minister, and a member of the Shiloh (Colored) Church" in Philadelphia, but was "unanimously excluded" from its ranks. ${ }^{12}$

In March 1863, the Rev. Dr. H. Parker Gloucester, yet another African American minister, called on the president. He "believed that colored people could fight as well as white men if they had sufficient cause to impel them to do it," and was inspired by Lincoln's announcement that blacks would be eligible for military service. ${ }^{13}$ African Americans

8. Lincoln to John Palmer Usher, Washington, 30 January 1863, photocopy of a copy, Phillip W. Magness, "Lincoln and Colonization," https:/ / www.essentialcivilwar curriculum.com/lincoln-and-colonization.html.

9. New York Tribune, 20 February 1863.

10. Providence Evening Bulletin, 3 November 1881.

11. Edwin S. Redkey, "Black Chaplains in the Union Army," Civil War History 33 (1987): 343.

12. Philadelphia Evening Telegraph, 20 October 1866; Philadelphia National Baptist, 21 November 1872.

13. Edward Gilbert, speech in New York on 11 June 1863, New York Times, 12 June 1863. 
in Gloucester's home town of Poughkeepsie, New York, were trying to raise a 10,000-man all-black army. It was to be called the "Fremont Legion," commanded by General John C. Frémont, a hero to blacks because of his 1861 unilateral decision to free slaves in Missouri. The radical abolitionist/journalist Jane Gray Swisshelm described Gloucester as "a polished gentleman, the son of a Kentucky slave." He "appears to have a small mixture of Caucasian blood" and "has entered into the business of raising the Fremont Legion with great spirit and has had several interviews with the President, by whom, he says, he has been most cordially received and assured that the legion shall be heartily welcomed to the service, and their wishes respected in the choice of their commander." 14 Another reporter similarly noted that Gloucester "has been holding interviews with President Lincoln nearly every day for over a week" and has also been the "guest of Mrs. Lincoln on one or two occasions. ${ }^{15} \mathrm{~A}$ Washington newspaper said that he had arrived around March 16, and that two days later Gloucester "gave an interesting account of the interview of the delegation with the President and Gen. Fremont, by both of whom they were cordially received."16 (It is not clear if Gloucester was alone or accompanied by others, nor is it certain that Lincoln met with him/them more than once in March. $)^{17}$

Gloucester presented Lincoln with an appeal that blacks in Poughkeepsie had adopted in late February: it thanked the president "for proclaiming liberty to the suffering millions of our oppressed fellow countrymen. . . . We prayed for a deliverer likened unto Moses; ... . believing that our prayer has been answered, and that God has raised up your Excellency as a deliverer, and a lamp by which our feet are guided into the paths of liberty." Observing that blacks had fought in earlier wars as loyal Americans, they declared their willingness "to follow the example of our fathers, and rally to our country's call. We have been called cowards. We deny the charge. It is false." They "humbly" asked Lincoln "to accept the service of the Fremont Legion."18

A leading African American abolitionist, James W. C. Pennington of Poughkeepsie, worried that Gloucester "has undertaken a big thing"

14. Jane Gray Swisshelm in the Chicago Journal, 29 March 1863, copied in the Milwaukee Sentinel, 13 April 1863. It is not clear whether March 29 is the date of the Washington correspondence by Swisshelm or the date of the article's publication.

15. Washington correspondence, n.d., The Christian Recorder (Philadelphia), 28 March 1863.

16. Washington Republican, 18 March 1863, copied in Douglass's Monthly, June 1863.

17. Washington correspondence, n.d., The Christian Recorder (Philadelphia), 28 March 1863.

18. Ibid. 
but was sure that "he is the right man" for the job. ${ }^{19}$ On April 6, when Gloucester returned to Poughkeepsie, "the Sons and Daughters of Freedom" there adopted resolutions hailing him as "our American Kossuth" and stating "that we highly appreciate the kind reception given Dr. Gloucester by President Lincoln and his excellent lady, Mrs. Lincoln, and also by Gen. Fremont." 20

In early May, white abolitionists in New York established the Fremont Legion Committee to help Gloucester raise troops. Late that month, a subcommittee of that organization met with Lincoln, who made several points which he reiterated on June 1, when Gloucester and his brother James (a Presbyterian minister in Brooklyn), along with white allies, called at the White House. There the president told them

that the policy of the Government, so far as he represented it, and his will controlled it, was fixed, and that the Government would avail itself of any plausible instrumentalities to obtain the cooperation of the emancipated slaves of the South as a military organization; that we had been drifting to this result, and had partly been compelled to it by the exigencies of the war; that he was thoroughly in earnest in this purpose, and he only labored under embarrassment in regard to how to carry it out. He confessed the partial failure in recruiting colored troops both North and South, but admitted [admired?] their patriotism, their enthusiasm, and their devotion to the cause of liberty. Indeed, he could not very well account for the seeming possibility we had arrived at in this enterprise, which he deemed an essential one to an early and complete success of the Union arms.

He told the Gloucester brothers and their colleagues:

You ask a suitable command for Gen. Fremont? There I see difficulty. Gen. Fremont is the second officer in rank in the active service of the United States; a suitable command would certainly mean a department. I have not a department vacancy to give him; I do not think I would be justified in dismissing any commander of a department for the purpose of placing him upon duty as contemplated by your memorial.

Citing an anecdote allegedly involving the British playwright Richard Brinsley Sheridan, Lincoln then remarked, "You place me in the position of the English lord who, when told by his paternal relative

19. Poughkeepsie, New York, correspondence by J[ames] W. C. P[ennington], 8 April 1863, New York Anglo-African, 18 April 1863.

20. Poughkeepsie, New York, Daily Eagle, 8 April 1863, copied ibid. 
to take a wife, replied, 'whose wife shall I take, father?'" His administration "could not always carry out promises about special men, special numbers and special commands." Lincoln then showed the committee a map with shaded areas indicating where slaves were most numerous. Pointing to the territory around Vicksburg, Mississippi, he said, "My opinion is that the colored population will have to take these places and will have to hold them." He "hoped for cooperation from the negroes in that section to take Vicksburg and to hold it." He had "explained that matter to various officers of high rank," but had "always found on these occasions that I ran afoul of somebody's dignity." He "could not prevail on them, because they had stars on their shoulders." He continued, "I would like anybody who can to undertake the matter. I believe Gen. Fremont peculiarly adapted to this special work. I would like to have him do it." He "assured them that he would do all in his power to forward the movement" and "that if they had the entire ten thousand troops they promised raised, he would give Gen. Fremont a department that very morning. He was disposed, in that case, to waive obstacles." ${ }^{21}$

Later that day (June 1), Lincoln wrote to Charles Sumner to explain that if there was "a fair prospect that a large force of this sort could thereby be the more rapidly raised," he would ignore the rule against having "troops raised on any special terms, such as to serve only under a particular commander, or only at a particular place or places" and "cheerfully" place Frémont in command of the 10,000 blacks and whatever whites could be added. But he could not create a new department for the Pathfinder because there were not enough spare troops, nor could he appoint the Pathfinder to head an existing department because there were insufficient grounds "to relieve the present commander of any old one." Moreover, in "the raising of the colored troops, the same consent of Governors would have to be obtained as in case of white troops, and the government would make the same provision for them during organization, as for white troops." 22

The following month, a convention of blacks met in Poughkeepsie to promote the enlistment of 10,000 blacks. ${ }^{23}$ Attendees listened to several speeches, approved a manifesto, and invited William Whiting,

21. I have conflated three similar accounts of this meeting: New York Times, New York World, New York Herald, 12 June 1863.

22. Roy P. Basler et al., eds., Collected Works of Abraham Lincoln, 9 vols. (New Brunswick: Rutgers University Press, 1953-55, for the Abraham Lincoln Association), 6:242243.

23. Rochester Union, 23 July 1863, copied in the Washington Daily National Intelligencer, 27 July 1863. 
the Solicitor of the War Department, to speak. Whiting replied with a long letter that concluded: "Abraham Lincoln takes no backward step... . The President wishes the aid of all Americans, of whatever descent or color, to defend the country. He wishes every citizen to share the perils of the contest, and to reap the fruits of victory." ${ }^{24}$ Here was a hint that if blacks served in the armed forces, they would receive citizenship rights.

Ultimately, nothing came of the Fremont Legion proposal. The recruiters failed to meet their goal, partly because other states were offering generous bounties to New York blacks as an inducement to join their regiments. Frémont himself was unenthusiastic. ${ }^{25}$ Moreover, the Democratic Governor of New York, Horatio Seymour, refused to cooperate, declaring that he opposed "the whole system of using Negro regiments" on principle. When Lincoln was urged to grant "authentications" allowing the recruitment of black troops in New York without gubernatorial approval, he refused to override Seymour on procedural grounds; governors were instrumental in raising troops, and he had already clashed unhappily with Seymour's predecessor over that very matter. ${ }^{26}$

In August 1863, a dozen African American Baptist ministers visited the White House seeking authorization to preach before units of the United States Colored Troops. ${ }^{27}$ Lincoln heard them out, "then made some interesting remarks," following which he gave the chairman a letter: "To whom it may concern: To-day I am called upon by a committee of colored ministers of the Gospel, who express a wish to go within our military lines and minister to their brethren there. The object is a worthy one, and I shall be glad for all facilities to be afforded them which may not be inconsistent with or a hindrance to our military operations." 28

The previous month, the War Department had officially appointed the first black chaplain. The 14 African Americans to serve as chaplains

24. William Whiting to Edward Gilbert, Washington, 18 July 1863, The Liberator (Boston), 31 July 1863.

25. Frémont to Charles Sumner, New York, 9 June 1863, Lincoln Papers, Library of Congress.

26. Edward Gilbert to Edwin Stanton, New York, 12 October 1863, in Ira Berlin et al., eds., The Black Military Experience (New York: Cambridge University Press, 1982), 105-107.

27. Washington Evening Star, 26 August 1863.

28. Washington Chronicle, 26 August 1863; Lincoln, "To whom it may concern," Washington, 21 August 1863, Basler et al, eds., Collected Works, 6:401. 
in the Union Army were officers, but they did not command troops, nor did whites have to salute them. The other 99 chaplains attached to black regiments were white. ${ }^{29}$

In June 1864, some of Washington's black Roman Catholics sought presidential assistance in raising money to build a chapel and a school for African Americans. They were denied access to the sanctuary of the principal Roman Catholic church in town, and their children were barred from public schools. Since Sunday schools of various denominations traditionally held picnics on the Fourth of July in Washington's parks, they thought that perhaps they could have a festival on the White House grounds. A parish priest had suggested that Edward McManus, an Irish doorkeeper at the Executive Mansion who served as superintendent of Sunday schools for the priest's church, consult the commissioner of public buildings, Benjamin Brown French, about obtaining the necessary permission. He did so and learned that the president must approve any such request. So a delegation of three blacks, led by successful businessman Gabriel Coakley, visited the White House and asked Lincoln's approval of their plan. The president replied to Coakley, "Certainly you have my permission. Go over to General French and tell him so." French provided the necessary document, which Coakley presented to Lincoln on June 30. The president endorsed it then and there: "I assent." As he handed it back to Coakley, he wished him and his friends success. Four days later, hundreds of blacks entered the White House grounds, where a festive atmosphere prevailed and a substantial sum was raised. ${ }^{30}$ An observer noted in his diary: "The colored people celebrate a picnic in the President's grounds. A stranger would imagine himself in the palace gardens of [Emperor Faustin] Soulouque of Hayti. Negroes [were] in hacks, with standards on gayly-caparisoned horses, and generally in the costume of the Southern aristocracy." ${ }^{\prime \prime 1}$

29. Redkey, "Black Chaplains," 332.

30. Gabriel Coakley to Benjamin Brown French, Washington, 27 June 1864, and French to Coakley, Washington, 30 June 1864, both reproduced in D. I. Murphy, "Lincoln: Foe of Bigotry," America, 11 February 1928, 432-433; Morris J. MacGregor, The Emergence of a Black Catholic Community: St. Augustine's in Washington (Washington: Catholic University of America Press, 1999), 3-5, 36-39; Basler et al., eds., Collected Works, 7:419: Benjamin Quarles, The Negro in the Civil War (New York: Russell \& Russell, 1953), 253; Washington correspondence, 8 July 1864, New York Anglo African, 23 July 1864.

31. William E. Doster, Lincoln and Episodes of the Civil War (New York: G.P. Putnam's Sons, 1915), 241 (diary entry for 4 July 1864). 
Democrats were indignant. White Washingtonians were reportedly "much exercised" by the president's decision to allow the picnic. ${ }^{32}$ The Albany Argus exclaimed that up until then, "no body of citizens had been allowed to assemble there for purposes of diversion-not even white Sabbath school children!"33 A Pennsylvania newspaper protested that within and around Washington there "are thousands of wounded and languishing white men whose parched lips and fevered brows have not the rich cold lemonade, nor the balmy cool shade there furnished to that motl[e]y crowd of reveling niggers." ${ }^{34}$ An Ohio soldier wrote home: "On the Fourth of July there was a nigger picnic on the White House grounds, while white soldiers stood guard around. Don't that beat h[el]1!" 35 The president "looked on and enjoyed it hugely," according to an Indiana paper, which averred that the "same spot would have been refused the white children of Washington for a similar purpose." The editor exclaimed: "God save the Republic!"36

$* * *$

Later that month, some Protestants followed the Roman Catholics' lead. The superintendent of Washington's Third Colored Baptist Sabbath School sought permission for another fund-raising event to be held on the Executive Mansion grounds. It was described as a "demonstration of the appreciation of the colored people of the much-desired and highly appreciated privileges they are permitted to enjoy since the freeing of the slaves and abolishing of the black laws of the District of Columbia." ${ }^{37}$ The money raised would be used to purchase a banner for the school "to be called 'The Banner of Freedom,' and which was to contain a life-size picture of President Lincoln, together with a design representing the freeing of slaves from bondage to freedom." Lincoln approved the request, and on August 4 more than 400 African Americans attended the celebration, during which the organizer of the affair "thanked the President for granting the use of the grounds and doing so much for the colored people." Because that day had been officially designated one of national humiliation and prayer, the event began with religious exercises, after which

32. Pittsfield, Massachusetts, Sun, 27 July 1864.

33. Albany Argus, n.d., copied in the Louisville Daily Democrat, 16 August 1864. Similarly, a Washington paper observed that "[i]n our recollection, that space has never been used for such a purpose." Washington National Intelligencer, 6 July 1864.

34. North Branch Democrat (Tunkhannock, Pennsylvania), 20 July 1864.

35. Dayton Daily Empire, 29 July 1864.

36. Plymouth, Indiana, Democrat, 28 July 1864.

37. Washington Evening Star, 3 August 1864. 
the assembly gave themselves up to social enjoyment. Watermelons, cantaloupes, smaller fruits, cakes, lemonades, and other refreshments were spread out in abundance. Swings were suspended from the branches of the trees, and promenading parties continually moved about. All seem to enjoy themselves hugely. Outside the grounds the scene was equally animated. Numerous tables, for the sale of refreshments occupied every available space and trade was brisk. ${ }^{38}$

Local Democratic papers denounced both Lincoln and the event: "The grounds, held by all patriots as something set apart and sacred, because invested with a national character, were prostituted and disgraced by the erection of stands for negro merchants to vend fruits and cakes and drinks to negro customers," fulminated the Washington Constitutional Union.

Negro speeches were made... Now, mark you, these were negroes who did these things, and did it with the high approval and warm commendation of our president. But the permission has been asked for the use of the public grounds around the White House for picnic purposes by Sabbath Schools of white men and ladies, and permission was refused! . . . But the negro is wooed to accept the gracious permission-nay, it may be, the urgent request-and the aghast country beholds the terrible spectacle of white men rudely spurned in requesting a privilege most eagerly anxiously thrust forward to the blacks. ${ }^{39}$

A paper in nearby Georgetown similarly bemoaned the fact that "the grounds of the house furnished by the people, by the white people of the country, were again polluted by the escapades of a negro picnic." The editors roundly criticized Lincoln: "his demagoguism may lead him to affect, and to induce others to believe, in social equality; but his partisans are few in number; and no sensible man credits his sincerity or the sanity of his followers." 40

In September 1864, five African American clergymen from Baltimore presented Lincoln with an ornate Bible as "a token of respect and

38. Washington Evening Star, 5 August 1864. J. R. Pierre, the superintendent of the Third Colored Baptist Sabbath School, had written to Lincoln on July 23. B. B. French replied two days later, indicating that the president's approval was necessary.

39. Washington Constitutional Union, n.d., copied in the Columbus Ohio Statesman, 17 August 1864.

40. Georgetown, D.C., Evening Union, 5 August 1864. 
gratitude to him for his active part in the cause of emancipation." 41 He shook the hand of each member of the delegation, whereupon their leader, Samuel W. Chase, said:

The loyal colored people of Baltimore have entrusted us with authority to present this Bible as a testimonial of their appreciation of your humane conduct towards the people of our race.... Since our incorporation into the American family we have been true and loyal, and we are now ready to aid in defending the country, to be armed and trained in military matters, in order to assist in protecting and defending the star-spangled banner. Towards you, sir, our hearts will ever be warm with gratitude. We come to present to you this copy of the Holy Scriptures, as a token of respect for your active participation in furtherance of the cause of the emancipation of our race. This great event will be a matter of history. Hereafter, when our children shall ask what mean these tokens, they will be told of your worthy deeds, and will rise up and call you blessed.

In accepting the gift, Lincoln apologized for not having prepared a formal response:

This occasion would seem fitting for a lengthy response to the address which you have just made. I would make one, if prepared; but I am not. I would promise to respond in writing, had not experience taught me that business will not allow me to do so. I can only now say, as I have often before said, it has always been a sentiment with me that all mankind should be free. So far as able, within my sphere, I have always acted as I believed to be right and just; and I have done all I could for the good of mankind generally. In letters and documents sent from this office I have expressed myself better than I now can.

Lincoln went on to describe the Bible as "the best gift God has given to man. All the good the Saviour gave to the world was communicated through this book. But for it we could not know right from wrong. All things most desirable for man's welfare, here and hereafter, are to be found portrayed in it. To you I return my most sincere thanks for the very elegant copy of the great Book of God which you present."

Lincoln "spent some time in examining the present," and expressed himself "highly pleased." After a "pleasant conversation," the 
ministers shook the president's hand "and bade him adieu, wishing him great success in his office, and re-election for another four years." ${ }^{42}$

In addition to religious leaders and their allies, other blacks called at the White House to make political appeals. As Clarence Lusane noted in The Black History of the White House, during Lincoln's presidency, "political access to the White House had been extended to the black community for the first time in U.S. history." Not only luminaries like Frederick Douglass and Sojourner Truth, but also "many lesserknown activists and ordinary African Americans met with him there as well. The significance of these encounters cannot be overstated." The "multiracial space that Lincoln opened would be a critical new element in the ongoing struggle for black freedom and equality." 43

In August 1863, Frederick Douglass called on Lincoln to discuss several matters. He later described his reception: upon arrival at the Executive Mansion, he found the stairway jammed with white office seekers, and since he "was the only dark spot among them," he expected that he would have "to wait at least half a day." But, as he reported, "in two minutes after I sent in my card, the messenger came out, and respectfully invited 'Mr. Douglass' in. I could hear, in the eager multitude outside, as they saw me pressing and elbowing my way through, the remark, 'Yes, damn it, I knew they would let the nigger through.'" The president greeted him, as Douglass put it, "just as you have seen one gentleman receive another, with a hand and voice well-balanced between a kind cordiality and a respectful reserve." Douglass was immediately taken with the president: "I never met with a man, who, on the first blush, impressed me more entirely with his sincerity, with his devotion to his country, and with his determination to save it at all hazards." ${ }^{44}$ Douglass described the interview as "a man in a low condition, meeting a high one. Not Greek meeting Greek, exactly, but railsplitter meeting nigger." He was impressed by the president's habit of calling him "Mr. Douglass." 45 In a letter recounting this conversation, Douglass wrote: "My whole interview

42. Basler et al., eds., Collected Works, 7:542; Washington National Intelligencer, Washington National Republican, 7 September 1864; A. W. W[ayman] to the editor, Baltimore, 4 October 1864, Christian Recorder (Philadelphia), 15 October 1864.

43. Lusane, The Black History of the White House (San Francisco: City Lights Books, 2011), 198.

44. Douglass's speech of 4 December 1863, in John W. Blassingame et al., eds., The Frederick Douglass Papers. Series One. 5 vols. (New Haven: Yale University Press, 19791992), 3:606.

45. Speech of 13 January 1864, New York Times, 14 January 1864. 
with the President was gratifying and did much to assure me that slavery would not survive the War and that the country would survive both slavery and the War." ${ }^{\prime 6} \mathrm{He}$ said that while at the White House, he "felt big." 47

In 1864, after Douglass gave a lecture describing this interview, the Philadelphia Age predicted that "[w]ith negro picnics in the White House grounds, and negro cronies in the White House itself, displaying their teeth at the Presidential wit, white people will have to wait a long time for their turn." To the editors of that Democratic paper, it looked "as if Mr. Lincoln was like the conscientious actor, who, when he played Othello, insisted on blacking himself all over." 48

On March 3, 1864, two educated black men from New Orleans-Jean Baptist Roudanez, an engineer, and E. Arnold Bertonneau, a wine merchant and former officer in the Union army-presented Lincoln a petition signed by several hundred African American residents of the Crescent City. It asserted that "We are men" and asked the president and Congress to "treat us as such." It also called for voting rights to be extended to Louisiana's blacks. ${ }^{49}$ Roudanez reported that "President Lincoln listened attentively to our address" and "sympathized with our object." 50 Ten days later, Lincoln wrote to the governor of Louisiana to suggest that a new constitution of his state-to be adopted soon-should enfranchise at least some blacks and thus help "keep the jewel of liberty within the family of freedom." 51

On April 29, another delegation of African Americans from the South presented a similar petition to Lincoln, asking him to support black enfranchisement. The five callers, North Carolinians all, did not resemble the urbane, freeborn New Orleans visitors of the previous month; four of them were unpolished former slaves (a brick mason, a barber, a farmer, and a preacher), led by Abraham H. Galloway, a handsome, proud, fiery abolitionist and Union spy in his mid-twenties. ${ }^{52}$ According to the preacher in the group, Lincoln "didn't tell us to go

46. Douglass to George Luther Stearns, Philadelphia, 12 August 1863, copy, Records of the Free Military School for Command of Colored Regiments, Historical Society of Pennsylvania.

47. Blassingame et al., eds., Douglass Papers, 3:606.

48. Philadelphia Age, 27 September 1864.

49. The Liberator (Boston), 1 April 1864.

50. Boston Daily Advertiser, 13 April 1864, copied in The Liberator (Boston), 15 April 1864.

51. Lincoln to Michael Hahn, Washington, 13 March 1864, Basler et al., eds., Collected Works, 7:243.

52. David S. Cecelski, The Fire of Freedom: Abraham Galloway and the Slaves' Civil War (Chapel Hill: University of North Carolina Press, 2012), 115-127. 
round to the back door, but, like a true gentleman and noble-hearted chief, with as much courtesy and respect as though we had been the Japanese Embassy, he invited us into the White House." After reading their petition, Lincoln spoke with them "freely and kindly," saying among other things "that he had labored hard and through many difficulties for the good of the colored race, and that he should continue to do so, and in this matter would do what he could for us, but as it was a matter belonging to the State it would have to be attended to in the reconstruction of the state. He was glad to see colored men seeking for their rights, and said that this was an important right which we, as a people, ought to have." After their long interview-during which the president's interlocutors requested and received "his sympathies and promises to do for us all he could" - they "took a hearty shake" of Lincoln's hand "and bid farewell!" 53

That same month, Caroline Johnson of Philadelphia, a former slave, presented the First Couple with a collection of wax fruits and a stemtable to express her gratitude for the president's emancipation policies. Accompanied by James Hamilton, the minister of her church, she called at the Executive Mansion where the Baptist divine made a brief speech and then invited Mrs. Johnson to say a few words. She nervously worked up the courage to speak: "Mr. President, I believe God has hewn you out of a rock, for this great and mighty purpose. Many have been led away by bribes of gold, of silver, of presents; but you have stood firm, because God was with you, and if you are faithful to the end, he will be with you." Lincoln "briefly responded, returning thanks for the beautiful present, referring to the difficulties with which he had been surrounded, and ascribing the wondrous changes of the past three years to the rulings of an all-wise Providence." With tears in his eyes, he concluded by telling Mrs. Johnson: "You must not give me the praise- it belongs to God." ${ }^{\prime 54}$

53. New Bern, North Carolina, correspondence by "Reporter," 15 June 1864, New York Anglo-African, 2 July 1864.

54. Washington correspondence by "Sojourner," 5 April 1864, Newark Daily Advertiser, 6 April 1864; letter to the editor by “Mrs. C" [Philadelphia], 6 March 1865, National Antislavery Standard (New York), 11 March 1865. According to the account by Mrs. C (a Quaker woman), Mrs. Johnson desired to express her gratitude to the president by making a gift for him. She did so and wanted her minister, James Hamilton, to present it. Her friend Mrs. C insisted that she herself make the presentation in conjunction with Hamilton. Mrs. C wrote: "She concluded to do so, and asked for an introductory letter to the President, which was given her. Isaac Newton, who is at the head of the Agricultural Department, and the President's wife, were written to, and the answer was, that 'she would be received.'" Mrs. Lincoln was "exceedingly pleased" with the gift. French, Witness to the Young Republic, 448 (entry for 6 April 1864). 
Later that April, Lewis H. Putnam, a black New Yorker who (like many other blacks) had long been active in the colonization movement, called on Lincoln to discuss African American troops. The president referred him to Secretary of War Edwin Stanton with a note: "please see L. H. Putnam, whom you will find a very intelligent colored man; and who wishes to talk about our colored forces, their organization, \&c." 55 Putnam may also have brought up his elaborate plans to promote emigration to Liberia. ${ }^{56}$

In February 1865, another black champion of colonization, Martin R. Delany, a physician and newspaper editor, also came to advise the president about African American soldiers. Delany remembered that Lincoln met him with "a generous grasp and shake of the hand." He noted that his host was "[s]erious without sadness, and pleasant withal." As Delany outlined his plan for an all-black army, Lincoln was "a patient audience." ${ }^{\prime 77}$ After hearing him out, the president sent Delany to Stanton with a note: "Do not fail to have an interview with this most extraordinary and intelligent black man." ${ }^{58}$ Later that month, Delany was appointed a major, thus becoming the highest-ranking African American line officer in the Union army.

Occasionally, Lincoln invited African Americans to the White House to discuss public affairs. In August 1862, he met with five leading members of Washington's black community to enlist their support for colonization. ${ }^{59}$ Reportedly, he "received the delegation with great kindness, shaking hands very cordially with each one." During his remarks, he referred to them as "intelligent colored men" and said, "Your race are suffering, in my judgment, the greatest wrong inflicted on any people." His encouragement of colonization to Central America on that occasion has been interpreted as evidence of Lincoln's deep-dyed racism, but as he suggested to his callers, insofar as African Americans lagged behind whites intellectually, it was because

55. Lincoln to Stanton, Washington, 11 April 1864, Basler et al., eds., Collected Works, 7:295. On Putnam, see Howard H. Bell, "The Negro Emigration Movement, 1849-1854: A Phase of Negro Nationalism," Phylon Quarterly 20 (1959): 132-142.

56. R. J. M. Blackett, The Slave's Quest for Freedom: Fugitive Slaves, the 1850 Fugitive Slave Law, and the Politics of Slavery (Cambridge: Cambridge University Press, 2018), 115-123.

57. Frank A. Rollin [nom de plume of Frances Anne Rollin], Life and Public Services of Martin R. Delany, Sub-assistant Commissioner, Bureau Relief of Refugees, Freedmen, and of Abandoned Lands, and Late Major 104th U. S. Colored Troops (Boston: Lee and Shepard, 1868), 166.

58. Lincoln to Stanton, Washington, 8 February 1865, Basler et al., eds., Collected Works, 8:272.

59. Kate Masur, "The African American Delegation to Abraham Lincoln: A Reappraisal," Civil War History 56 (2010): 117-144. 
they were oppressed, not because they were biologically inferior. ${ }^{60} \mathrm{He}$ asked the black guests to spearhead colonization because any pioneering efforts in that cause had to be led by men "capable of thinking as white men, and not those who have been systematically oppressed." He clearly believed that black men were able to think as well "as white men" could think, once they were no longer oppressed. ${ }^{61} \mathrm{He}$ further remarked, "You and we are different races. We have between us a broader difference than exists between almost any other two races.... This physical difference is a great disadvantage to us both, as I think your race suffer very greatly, many of them by living among us, while ours suffer from your presence." That was a blunt, accurate description of race relations in mid-19th century America, not a racist commentary. Though some abolitionists found his remarks condescending and his enthusiasm for colonization offensive, the Radical Republican editor John W. Forney described the event as a historic occasion: "The negro may well say that under President Lincoln he has had his first hearing in the White House. Other presidents have bought and sold him, and driven him from the territories, and closed their eyes to the nefarious system under which he was captured in Africa and dragged over the ocean in chains. But President Lincoln has listened to his story and given him counsel and advice." ${ }^{2}$

Some African American leaders praised Lincoln, including Henry Highland Garnet, an eminent Presbyterian minister in Washington who called the president's scheme to establish a haven for freedmen in Central America "the most humane, and merciful movement which this or any other administration has proposed for the benefit of the enslaved." Garnet considered "the free and voluntary emigration of our people to any portion of the globe" to be "among the most sacred of human rights" and believed "this is one of God's ways by which the families of the earth are improved and advanced in national character." Rhetorically he asked, "Where are the freed people of the South to seek a refuge? Neither the North, the West, nor the East will receive them. Nay-even our colored people of the North do not want them here. They all say, [both] white and black-'these Southern negroes if they come here, will reduce the price of labor, and take the bread out of our mouths.'" Garnet feared that newly emancipated slaves might be captured by the rebel army and re-enslaved (which did happen to

60. Phillip Shaw Paludan, "Lincoln and Colonization: Policy or Propaganda?" Journal of the Abraham Lincoln Association 25 (2004): 23-37.

61. Basler et al., eds., Collected Works, 5:371-372.

62. Washington correspondence by “Occasional” (John W. Forney), 17 August 1862, Philadelphia Press, 18 August 1862. 
some blacks later in the war): "if Jeff Davis does not emancipate [the slaves of the Confederacy], and our government does not provide a territory on this continent as a refuge for those who have been freed by our armies, then the condition of these people will be worse than ever it was before. When they again fall into the hands of their tormentors, they will be tortured as human beings never were in this world." (Confederate forces did indeed torture, murder, and mutilate some African American troops who had surrendered. In liberated areas of Mississippi and Louisiana, Confederate raiders slaughtered hundreds of former slaves who were working plantations as hired hands with inadequate military protection. ${ }^{63}$ But if Lincoln's plan were adopted, Garnet predicted, "hundreds of thousands of men will be saved, and the Northern bugbear 'they will all come here' be removed." 64

Another prominent black leader, the abolitionist minister Henry McNeal Turner, defended the president. "Mr. Lincoln loves freedom as well as any one on earth," he wrote in September, shortly after the president issued the Emancipation Proclamation. "Mr. Lincoln is not half such a stickler for colored expatriation as he has been pronounced," Turner insisted. The colonization proposal he made was less a practical plan than a "strategic move upon his part in contemplation of this emancipatory proclamation just delivered. He knows as well as any one, that it is a thing morally impracticable, ever to rid this country of colored people unless God does it miraculously, but it was a preparatory nucleus around which he intended to cluster the raid of objections while the proclamation went forth." To assuage the fears of anxious whites, "the President stood in need of a place to point to," a place where blacks could, with government support, resettle if they wished. ${ }^{65}$

Turner's account seems based on what the president told him. James Mitchell stated that Turner "had sought an interview on his own responsibility with the President in relation to the $\$ 600,000$ emigration fund." ${ }^{66}$ Presumably Lincoln granted that interview, though it is

63. Gregory J. W. Urwin, ed., Black Flag over Dixie: Racial Atrocities and Reprisals in the Civil War (Carbondale: Southern Illinois University Press, 2004); Nicholas Guyatt, "'An Impossible Idea?': The Curious Career of Internal Colonization," Journal of the Civil War Era 4:2 (June 2014), 242.

64. Garnet to [Thomas Hamilton], n.p., n.d., New York Anglo-African, n.d., copied in San Francisco Pacific Appeal, 11 October 1862.

65. Jean Lee Cole and Aaron Sheehan-Dean, eds., Freedom's Witness: The Civil War Correspondence of Henry McNeal Turner (Morgantown: West Virginia University Press, 2013), 71.

66. New York Anglo-African, n.d., copied in the San Francisco Pacific Appeal, 20 September 1862. 
not documented. There is also reason to believe that Garnet met with the president in $1861 .{ }^{67}$ The meaning of Turner's account is somewhat hard to glean from his rather opaque language, but he hints broadly that he is reporting Lincoln's views rather than merely speculating about them. When Turner stated that "Mr. Lincoln is not half such a stickler for colored expatriation as he has been pronounced," he immediately added: "I am responsible for the assertion," by which he evidently meant "I know whereof I speak." Turner provided a similar hint after his statement: "He knows as well as any one, that it is a thing morally impracticable, ever to rid this country of colored people unless God does it miraculously, but it was a preparatory nucleus around which he intended to cluster the raid [rain?] of objections while the proclamation went forth in the strength of God and executed its mission." Immediately after this analysis of the president's intention, Turner adds: "I do not wish to trespass upon the key that unlocks a private door for fear that I might lose it, but all I will say is that the President stood in need of a place to point to." Turner's reference to the key and private door apparently meant: "I enjoyed access to the president which I do not want to jeopardize by revealing too much of what he told me, but I will at least say this."

Turner was almost certainly not expressing his own opinion of Lincoln, whom he had likened in July 1862 to a hard-hearted "Mystic Pharaoh" refusing to comply with "Heaven's demand" that he free his country's slaves. ${ }^{68}$ In 1864, he mocked the contention "that Mr. Lincoln was obliged to court the affections of the Democratic parties, to secure the co-operation of the whole North" as "nothing more than a farce." 69

A year later, Lincoln met with another delegation of five black leaders in which the subject colonization was treated, at least indirectly. A delegation from the African Civilization Society called at the White House on November 5, 1863, to request $\$ 5000$, ostensibly for general operations. But that black organization, founded by Henry Highland Garnet, was primarily devoted to encouraging emigration, and their request was evidently for funds to convey African Americans immigrants to British Honduras. The delegation was headed by George

67. Richard Greener said that Garnet helped J. Sella Martin win his assignment to accompany Thurlow Weed and Archbishop John Hughes on their trip to England, where all three would help publicize and explain the Northern cause. He may have spoken with Lincoln then, though no record of such a meeting is known. New York Herald, 25 February 1881.

68. Washington correspondence, 2 July 1862, Christian Recorder (Philadelphia), 12 July 1862.

69. Harrison's Landing, Va., correspondence by Turner, 10 September 1864, ibid., 17 September 1864. 
W. La Vere, who had succeeded Garnet as president of the Society. He was accompanied by the Society's secretary, Henry Wilson, and its directors, Richard H. Cain, P. S. Porter, and William Anderson. For Lincoln's signature, Mitchell drafted a document appropriating the money, but the president evidently did not sign it. No account of the meeting is extant. ${ }^{70}$

Two years later, Lincoln invited Frederick Douglass to discuss the necessity of encouraging slaves to flee to Union lines. ${ }^{71}$ Douglass found the president's willingness to summon him remarkable; months after that meeting, he wrote that Lincoln "knew that he could do nothing which would call down upon him more fiercely the ribaldry of the vulgar than by showing any respect to a colored man." Douglass added:

Some men there are who can face death and dangers, but have not the moral courage to contradict a prejudice or face ridicule. In daring to admit, nay in daring to invite a Negro to an audience at the White house, Mr. Lincoln did that which he knew would be offensive to the crowd and excite their ribaldry. It was saying to the country, I am President of the black people as well as the white, and I mean to respect their rights and feelings as men and as citizens. ${ }^{72}$

In 1865, Douglass told a Boston audience that a "noticeable feature" of Lincoln's "personal demeanor" was his ability "to talk easily and freely to a negro without reminding him that he was a negro." ${ }^{73}$ Much later, Douglass wrote: "In all my interviews with Mr. Lincoln I was impressed with his entire freedom from popular prejudice against the colored race. He was the first great man that I talked with in the United States freely, who in no single instance reminded me of the difference between himself and myself, of the difference of color, and I thought that all the more remarkable because he came from a State where there were black laws." ${ }^{74}$

$* * *$

70. Phillip W. Magness, “The British Honduras Colony: Black Emigrationist Support for Colonization in the Lincoln Presidency," Slavery \& Abolition 34 (2013), 39-60, DOI: 10.1080/0144039X.2012.709044

71. Frederick Douglass, Life and Times of Frederick Douglass (Hartford, Conn.: Park Pub., 1881), 435-437.

72. Manuscript of a speech given at Cooper Institute in New York, 1 June 1865, Douglass Papers, Library of Congress.

73. Speech given in Boston, 24 October 1865, The Liberator (Boston), 27 October 1865.

74. Allen Thorndike Rice, ed., Reminiscences of Abraham Lincoln by Distinguished Men of His Time (New York: North American Publishing, 1886), 193. 
When Lincoln was away from the White House, he showed no reluctance to greet blacks respectfully. In May 1862, he visited Washington's Columbia College Hospital, where nurse Rebecca Pomroy presented him first to the officers on the staff and then to members of the black kitchen crew.

"And who are these?" he asked in a kindly voice as three African American cooks came forward.

"This is Lucy, formerly a slave from Kentucky. She cooks the nurses' food." hers.

"How do you do, Lucy?" he asked as he extended his hand to shake

"And who are these on your left?"

"This is Garner, and this Brown. They are serving their country by cooking the low diet for our sickest boys."

"How do you do, Garner? how do you do, Brown?" he asked as he shook their hands.

The blacks were amazed and joyful; the whites on the staff were also amazed but not joyful. Nurse Pomroy quickly "became aware of a feeling of intense disapprobation and disgust among the officers, who a moment before had been all graciousness and suavity. Their conversation was afterwards reported to her. 'Anybody would know she was a Massachusetts woman,' they said, 'for no one else would do such a mean, contemptible trick as to introduce those d[amned] niggers to the President.'

'"Yes,' said the surgeon in charge, 'it was in Massachusetts that the first abolition egg was laid.'"

Even the hospital's patients felt insulted by the president's unusual cordiality to black people. ${ }^{75}$

Lincoln often visited a Washington camp housing refugee slaves (called "contrabands"). There a former slave, Mary Dines, recalled that the president "was very fond of the hymns of the slaves and loved to hear them and even knew most of them by heart." One Saturday, he and the First Lady attended a camp concert. As the black residents intoned hymns and patriotic airs, Lincoln wiped tears from his eyes. During the final number, "John Brown's Body," he "joined in the chorus and sang as loud as anyone there." Once or twice he choked up. On another visit, he asked to hear "some more good old hymns." When the African Americans obliged, he sang along with them. Mary Dines reported that "he was so tenderhearted that he

75. Anna L. Boyden, Echoes from Hospital and White House: A Record of Mrs. Rebecca R. Pomroy's Experience in War-times (Boston: D. Lothrop, 1884), 94-97. 
filled-up [i.e., his eyes teared up] when he went over to bid the real old folks good-by." He was, she said, "no President when he come to camp. He just stood and sang and prayed just like all the rest of the people." Whenever the older blacks got carried away and began shouting and yelling during prayers, "he didn't laugh at them, but stood like a stone and bowed his head." Mary Dines "said she really believed that the Holy Ghost was working on him." ${ }^{\prime 76}$

Lincoln was also cordial to the black employees at the White House. Rosetta Wells, a seamstress who did some sewing and mending for the First Family, recalled that "he treated the servants like 'people,' and would laugh and say kind things to them." 77 Echoing her, the former slave Elizabeth Keckly (Mrs. Lincoln's dressmaker and confidante) told a journalist, "I loved him [the president] for his kind manner towards me.... He was as kind and considerate in his treatment of me as he was of any of the white people about the white house." ${ }^{\prime 78}$ Peter Brown, a black waiter and butler, had a young son who spent much time at the Executive Mansion during the Civil War. He remembered that Lincoln "was kind to everybody" and "sympathized with us colored folks, and we loved him."79 The daughter of William Slade, head servant at the Executive Mansion, reported that the president "never treated [the White House staff] as servants, but always was polite and requested service, rather than demand it of them." ${ }^{80}$ Similarly, White House secretary William O. Stoddard reported that in dealing with the staff, Lincoln was not at all condescending; he "took their presence and the performance of their duties so utterly for granted. No one of them was ever made to feel, unpleasantly, the fact of his [or her] inferior position by reason of any look or word of the President." ${ }^{\prime 81}$

The best example of Lincoln's solicitude for black staff members was his treatment of William Johnson, a valet-cum-barber who accompanied the First Family on their rail journey from Springfield to Washington in 1861. (A journalist aboard that train described Johnson as "a very useful member of the party" whose "untiring vigilance" as "he took care of the Presidential party" was "entitled to high credit." $)^{82}$

76. John E. Washington, They Knew Lincoln (New York: E. P. Dutton, 1942), 84-87.

77. Rosetta Wells, ibid., 77-78

78. Keckly interviewed by Smith D. Fry, undated Washington letter, Lane County Journal (Dighton, Kansas), 11 July 1901.

79. Washington, They Knew Lincoln, 124-125.

80. Ibid., 100-101.

81. William O. Stoddard, Abraham Lincoln: The True Story of a Great Life (New York: Fords, Howard, \& Hulbert, 1884), 403.

82. Philadelphia Inquirer, 22 February 1861. 
At first, Johnson worked in the Executive Mansion as a porter, but the other African American employees, all light-skinned, objected to his dark complexion so strongly that Lincoln reassigned him as a furnace-keeper-cum-handyman. (The long-standing tendency of lightskinned American blacks to look down upon dark-skinned blacks has lately been denominated "colorism.") Johnson was identified in the 1861 Official Register of the United States as "W. H. Johnson, Fireman, President's House." Rather than have Johnson remain in the furnace room, Lincoln tried to find him a post outside the White House. Three days after his inauguration, he gave Johnson a recommendation: "To whom it may concern. William Johnson, a colored boy, and bearer of this, has been with me about twelve months; and has been, so far, as I believe, honest, faithful, sober, industrious, and handy as a servant." A few days later, Lincoln wrote to Navy Secretary Welles: "The bearer (William) is a servant who has been with me for some time \& in whom I have confidence as to his integrity and faithfulness. He wishes to enter your service. The difference of color between him \& the other servants is the cause of our seperation. If you can give him employment you will confer a favour on yours truly." 83 Nothing came of that overture.

Several months later, Lincoln wrote to Treasury Secretary Salmon P. Chase. "You remember kindly asking me, some time ago whether I really desired you to find a place for William Johnson, a colored boy who came from Illinois with me. If you can find him the place [I] shall really be obliged." ${ }^{4}$ In response, Chase appointed Johnson to a $\$ 600$-per-year job in his department. To enable him to earn more money, the president facilitated his efforts to moonlight for others. ${ }^{85}$ Johnson continued to work at the White House off and on as Lincoln's barber, valet, and bodyman. (He may have spent his mornings in the White House and afternoons in the nearby Treasury Department building, where he evidently acted as an assistant to the librarian of the Treasury, Samuel Yorke Atlee.) Occasionally Lincoln gave him checks for small amounts to supplement his modest salary.

When Johnson borrowed money to buy a house, Lincoln guaranteed the mortgage. In 1863, Johnson contracted smallpox (after returning with the president from their memorable trip to Gettysburg) and was

83. Lincoln to Welles, Washington, 16 March 1861, Basler et al., eds., Collected Works, $4: 288$.

84. Lincoln to Chase, Washington, 29 November 1861, ibid., 5:33.

85. Washington, They Knew Lincoln, 131-132. 
unable to sign his pay voucher. While Johnson was hospitalized, a journalist discovered the president counting out some greenbacks. Lincoln explained that such activity

is something out of my usual line, but a president of the United States has a multiplicity of duties not specified in the Constitution or acts of Congress. This is one of them. This money belongs to a poor Negro [Johnson] who is a porter in one of the departments (the Treasury) and who is at present very bad with the smallpox.... He is now in hospital and could not draw his pay because he could not sign his name. I have been at considerable trouble to overcome the difficulty and get it for him and have at length succeeded in cutting red tape ... I am now dividing the money and putting by a portion labeled, in an envelope, with my own hands, according to his wish. ${ }^{86}$

Soon thereafter, Johnson died. Lincoln bought a coffin, covered the cost of his burial, helped support his family, and retired his debts. Johnson had borrowed $\$ 150$, using Lincoln as a guarantor. When an official of the lending bank, William J. Huntington, told Lincoln that the loans would be forgiven, he replied, "No you don't. I endorsed the notes, and am bound to pay them; and it is your duty to make me pay them."

"Yes," said Huntington, "but it has long been our custom to devote a portion of our profits to charitable objects; and this seems to be a most deserving one."

When Lincoln demurred, Huntington said, "Well, Mr. Lincoln, I will tell you how we can arrange this. The loan to William was a joint one between you and the bank. You stand half of the loss, and I will cancel the other."

"Mr. Huntington, that sounds fair, but it is insidious; you are going to get ahead of me; you are going to give me the smallest note to pay. There must be a fair divide over poor William. Reckon up the interest on both notes, and chop the whole right straight through the middle, so that my half shall be as big as yours. That's the way we will fix it."

Huntington agreed, saying, "After this, Mr. President, you can never deny that you indorse the negro."

"That's a fact!" Lincoln exclaimed with a laugh; "but I don't intend to deny it." 87

86. Washington correspondence, 14 January 1864, Chicago Tribune, 19 January 1864.

87. Samuel Wilkeson, “How Mr. Lincoln Indorsed the Negro," Janesville (Wisconsin) Gazette, 23 July 1867. 
Lincoln helped his black barber/attendant, Solomon J. Johnson, win appointment to the Treasury Department post that William Johnson had held. A year later, he recommended Johnson for promotion. ${ }^{88}$

Lincoln also sought to help Samuel Williams, the 21-year-old son of a White House cook, "Aunt Mary" Williams. ${ }^{89}$ The young man was working as a barber in the Executive Mansion when the president wrote to Treasury Secretary Chase in July 1862: "The bearer of this, son of our cook, is a good barber, and a good boy generally, I believe. He had a position during the session of Congress, in which he gave entire satisfaction as I understand, but which came to an end by the adjournment. Please see him a moment, \& do something for him if you can." 90

Williams later said it was Lincoln's "high regard" for his mother which prompted him to write that recommendation. ${ }^{11}$ On September 10, 1862, Chase gave Williams a job in the Treasury Department, where he was employed for the next two decades.

The black man who worked most closely with Lincoln was William Slade, the lead White House servant and a prominent member of the city's African American elite. ${ }^{92}$ Edward Duffield Neill, who served as a White House secretary in the final year of Lincoln's administration, described Slade as a "faithful man, prudent and dignified." According to a historian who interviewed Slade's friends and family, he "had a wonderful disposition, never became excited, always could see the bright side of things, even when Lincoln was downcast and

88. Lincoln to Salmon P. Chase, Washington, 28 January 1864, Basler et al., eds., Collected Works, 7:156; Lincoln to Hugh McCulloch, Washington, 15 March 1865, ibid., 8:354.

89. David J. Gerleman, "A Good Boy Generally: Abraham Lincoln and Samuel Williams," Lincoln Editor: The Quarterly Newsletter of the Papers of Abraham Lincoln, 9 (July-September 2009).

90. Lincoln to Salmon P. Chase, Washington, 30 July 1862, record group 56, entry 210: part two, records of various divisions within the office of the secretary of treasury, Records of the division of appointments, correspondence of the division, applications and recommendations for positions in the Washington, D.C., offices of the Treasury Department, 1830-1910, National Archives, College Park, Maryland, ibid.

91. Samuel Williams to Robert Todd Lincoln, Washington, 28 August 1882, box 94, record group 107, entry 259: records of the chief clerk and the administrative assistant, records relating to personnel, general records, 1816-1899, applications for civilian appointments and regular army commissions, 1847-1887, National Archives, Washington, D.C., ibid.

92. Natalie Sweet, "A Representative 'of our people': The Agency of William Slade, Leader in the African American Community and Usher to Abraham Lincoln," Journal of the Abraham Lincoln Association 34:2 (Summer 2013): 21-41.

93. Edward D. Neill, Reminiscences of the Last Year of President Lincoln's Life (St. Paul, Minnesota: Pioneer Press, 1885), 16. 
needed a cheering, hopeful friend." In addition, he was "a great story teller," well known "for his collection of jokes and wisecracks." Slade performed several roles, among them butler, confidential messenger, presidential valet, boss of the black servants, and arranger of food service at public and private functions. With so many responsibilities, he was "in constant demand by his employer."94 Slade's daughter Katherine remembered that she had "stayed many nights in the White House with her parents when storms came up and they could not get home. She and her brother played with Tad, and he often came and played with them in their home." ${ }^{\prime 95}$

$* * *$

On April 4, 1865, two days after the Union Army captured Richmond, Lincoln toured the Confederate capital. As he and his party walked its streets, he grew weary and paused to rest. At that point, according to the journalist Charles C. Coffin, "an old negro, wearing a few rags, whose white, crisp hair appeared through his crownless straw hat, lifted the hat from his head, kneeled upon the ground, clasped his hands, and said, 'May de good Lord bress and keep you safe, Massa President Linkum.'" The president "lifted his own hat and bowed to the old man." Lincoln's gesture was, in Coffin's view, "a bow which upset the forms, laws, customs, and ceremonies of centuries. It was a death-shock to chivalry, and a mortal wound to caste." A white woman who was looking on turned away "with unspeakable contempt." To Coffin, the most impressive feature of that memorable day "was the respect which Lincoln showed to the poor creature when he removed his hat, while the old negro prayed God to bless him." ${ }^{\prime \prime 6}$

Three days later, Lincoln accompanied his wife and some friends on a rail trip to Petersburg. One member of the party, Charles Adolphe Pineton (the Marquis de Chambrun), recalled that their car

was an ordinary American car, and we took seats in its centre, grouping ourselves around Mr. Lincoln. In spite of the car's being devoted to Mr. Lincoln's special use, several officers also took their places in it without attracting any remark. Curiosity, it seems, also had induced the negro waiters of the [president's

94. Washington, They Knew Lincoln, 108.

95. Ibid., 105.

96. Coffin in Rice, ed., Reminiscences of Lincoln, 182; Richmond correspondence by Coffin in the Boston Journal, n.d., Littell's Living Age, 85:138 (8 April 1865); Coffin, "Late Scenes in Richmond," Atlantic Monthly, June 1865, 755; Coffin, Four Years of Fighting: A Volume of Personal Observation with the Army and Navy, from the First Battle of Bull Run to the Fall of Richmond (Boston: Ticknor and Fields, 1866), 512. 
ship, the] River Queen to accompany us. The President, who was blinded by no prejudices against race or color, and who had not what can be termed false dignity, allowed them to sit quietly with us. ${ }^{97}$

Another White House color line that Lincoln crossed was the one that barred blacks from attending purely social events, like a meal or a tea. President Theodore Roosevelt famously broke that color barrier in 1901 when he had Booker T. Washington to dinner. According to a historian of the White House, "no Negro received a social invitation to the White House before Booker T. Washington in 1901, nor did any thereafter for many years." ${ }^{\prime 98}$ But in the late summer of 1864, Lincoln did invite Frederick Douglass to tea at the Soldiers' Home, where the First Family resided during the warmer months. (The only precedent for such an invitation was set in 1799 at the President's House in Philadelphia, where John Adams hosted a dinner for a white Haitian diplomat and his black wife. ${ }^{99}$ In Douglass's autobiography, he described the circumstances:

At the door of my friend John A. Gray, where I was stopping in Washington, I found one afternoon the carriage of Secretary Dole [Commissioner of Indian Affairs William P. Dole], and a messenger from President Lincoln with an invitation for me to take tea with him at the Soldiers' Home ... Unfortunately, I had an engagement to speak that evening, and having made it one of the rules of my conduct in life never to break an engagement if [it were] possible to keep it, I felt obliged to decline the honor. I have often regretted that I did not make this an exception to my general rule. Could I have known that no such opportunity could come to me again, I should have justified myself in disappointing a large audience for the sake of such a visit with Abraham Lincoln. ${ }^{100}$

Historian James Oakes plausibly observed that "there is every reason to believe that Lincoln invited Douglass to the Soldiers' Home because he enjoyed Douglass's company as much as he valued Douglass's

97. Marquis de Chambrun, "Personal Recollections of Mr. Lincoln," Scribner's Magazine, January 1893, 28.

98. William Seale, The President's House: A History, 2 vols. (Washington, D.C.: White House Historical Association, 1986), 2:653.

99. Philippe R. Girard, "Trading Races: Joseph and Marie Bunel, a Diplomat and a Merchant in Revolutionary Saint-Domingue and Philadelphia," Journal of the Early Republic 30 (2010): 351-376. According to Girard, many historians have misidentified Joseph Bunel as a mulatto.

100. Life and Times of Douglass, 446-447. 
opinion." ${ }^{101}$ Douglass thought that Lincoln was friendly to him "because of the similarity with which I had fought my way up, we both starting at the lowest round of the ladder."102

What Frederick Douglass called Lincoln's "kindly disposition towards colored people" had its roots, at least in part, in the experiences he had during his 24 years in Springfield. ${ }^{103}$ As Richard Hart has shown, in the Illinois capital Lincoln knew many African Americans in the racially mixed neighborhood where he lived. ${ }^{104}$ His closest black friend was William Florville, his regular barber for whom he did legal work. ${ }^{105}$ Other African Americans whom he knew were Ruth Stanton and Mariah Vance (servants in his home), William Johnson (described above), the Reverend Mr. Henry Brown (a conductor on the underground railroad who led the Lincoln family horse in the president's funeral procession), ${ }^{106}$ Jameson Jenkins (another conductor on the underground railroad, a teamster, and a near neighbor), Spencer Donnegan (a barber and an active community organizer), and John Shelby (whom Lincoln rescued from a New Orleans jail by paying for his release). ${ }^{107}$

Lincoln's unfailing cordiality to African Americans, his willingness to meet with them in the White House, to honor their requests, to invite them to consult on public policy, to treat them with respect and kindness whether they were kitchen servants or leaders of the black community, to extend them invitations to attend receptions and tea, to sing and pray with them on their turf, to authorize them to hold events on the White House grounds-all those manifestations of an egalitarian spirit fully justified the tributes paid to him by Frederick Douglass, Sojourner Truth, Mary Dines, Elizabeth Keckly, and other African Americans. They also help explain why Douglass called Lincoln "emphatically the black man's president."

101. James Oakes, The Radical and The Republican: Frederick Douglass, Abraham Lincoln, and the Triumph of Antislavery Politics (New York: W. W. Norton, 2007), 238.

102. Rice, ed., Reminiscences of Lincoln, 193.

103. Manuscript of a speech given at Cooper Institute in New York, 1 June 1865, Douglass Papers, Library of Congress.

104. Richard E. Hart, "Springfield's African Americans as a Part of the Lincoln Community," Journal of the Abraham Lincoln Association 20:1 (Winter 1999): 35-54. See also Bonnie E. Paull and Richard E. Hart, Lincoln's Springfield Neighborhood (Charleston, South Carolina: The History Press, 2015).

105. Gossie Harold Hudson, "William Florville, Lincoln's Barber and Friend," Negro History Bulletin 37 (1974): 279-281.

106. Richard Hart, "Lincoln's Springfield: The Underground Railroad, Part 2," For the People: A Newsletter of the Abraham Lincoln Association 8:2 (Summer 2006): 1-2, 4-6.

107. Charles M. Segal, "Lincoln, Benjamin Jonas, and the Black Code," Journal of the Illinois State Historical Society 46:3 (Autumn 1953): 277-282. 